\title{
Mistaken for populism: Magufuli, ambiguity and elitist plebeianism in Tanzania
}

\author{
Dr. Dan Paget \\ Department of Political Science, University College London. \\ danpaget.com | d.paget@ucl.ac.uk
}

Forthcoming in the Journal of Political Ideologies.

January 2020.

\begin{abstract}
'The elite' in ideational conceptions of populism has gone ill-defined. This makes conceptions of populism elastic. This article asserts that a discourse should only qualify as populist if it constructs an elite that acts in its collective interests and possesses a majority of power across fields. These criteria narrow the definition of populism and reveals another type of discourse, christened here 'elitist plebeianism'. While populists bifurcate society between 'the people' and 'the elite', elitist plebeians trifurcate society between 'the common people', 'the elite' and a middle stratum. While populists vilify the elite, elitist plebeians heroise it and vilify the middle. In office, populists struggle to reconcile their power and their opposition to the powerful; elitist plebeians do not. This similarity in terms and structure facilitates the movement between populist and elitist plebeian discourses. That makes elitist plebeianism a ready-made script for so-called 'populists in power.' Tanzania provides proof of concept. Tanzania's opposition constructed CCM as a corrupt establishment. Magufuli and his party appropriated this discourse but relocated corruption from the elite to the bureaucracy and business, which they portrayed as less powerful than themselves; their discourse is not populist, but elitist plebeian.
\end{abstract}

Keywords: populism, discourse, elite, bureaucracy, corruption

Word count: 10,000

Acknowledgements: I would like to thank Michael Freeden and two anonymous reviewers for their comments and encouragement. My thanks go to Alastair Fraser, Portia Roelofs and Aikande Kwayu for their comments on earlier drafts of this article. I would also like to extend further thanks to and acknowledge the contributions of Aikande Kwayu, Erick Mwakibete, Athuman Mtulya, Deogratias Munishi, and other peers, who wish to remain anonymous. Their insights in conversation have significantly refined the arguments presented herein. All remaining errors are my own. 
Victory contains its own defeat for the populist. Populists, whether defined by the ideologies they espouse or the discourses they express, present themselves as champions of 'the people' against 'the elite'. The ascent to public office exacerbates the populist's struggle to maintain their distance from that elite. They employ numerous means to rhetorically reconcile their positions of power and their opposition to the powerful. Some portray themselves as under siege in their own government by a hostile state. Others continue the fight against an establishment which is not in government but in the heights of the economy, the media, or the international system. Others still forsake their populist messages once in office, or even avoid holding office altogether. This tension in populism stems from its ideational structure. By dividing society into 'the underdog' and 'the establishment', populists discursively hem the powerful together. Thereby, they become trapped by their own rhetoric. As they win power, they are hoisted by their own petards.

Several politicians have been classified as populists in sub-Saharan Africa. ${ }^{1}$ Among the most recent African politicians to join this canon is John Pombe Magufuli, the President of Tanzania. Sabatho Nyamsenda describes Magufuli's 'authoritarian populism'. ${ }^{2}$ Thabit Jacob and Rasmus Pedersen and Japhace Poncian characterise Magufuli as a populist and resource nationalist. ${ }^{3}$ The Economist dubbed him a populist. ${ }^{4}$ However, Magufuli has not struggled to reconcile his rhetoric with his high office. Far from underplaying his power and overplaying others', he inflates his power, and deflates others'. He leads the longest-ruling party in sub-Saharan Africa, Chama cha Mapinduzi $(\mathrm{CCM})$ or the 'Party of the Revolution', 5 and he declared that it would rule 'forever'. 6 
Magufuli's characterisation as a populist despite his easy relationship with power touches on an ill-resolved issue in the study of populism as a discourse or ideology, namely, the role of and the definition of 'the elite'. Scholars disagree whether 'the elite' is an essential aspect of populism. Conceptions of populism that incorporate this term frequently leave it ill-defined. This lax treatment of 'the elite' makes ideational concepts of populism elastic. The cases which have been subsequently classified as populist pull at the edges of the concept and frustrate attempts to incorporate all such cases into a coherent definition. This only exacerbates the definitional challenges plaguing the study of populism which Margaret Canovan elucidated in $1982 .^{7}$

To address this concept-stretching and mis-application, this article proposes a stricter conception of 'the elite' as constructed in populist discourse. In the search for a sharper definition of 'the elite', this article returns to Ernesto Laclau. Laclau stipulates that populists discursively divide society dichotomously into people and elite and imbue the latter with power. ${ }^{8}$ Three criteria follow about how a discourse must characterise 'the elite' to qualify as populist. First, collectively, an elite should have more power than any rival set of actors in the society. Second, it should have more power even when aggregating power across each field in which power is imagined. Third, the actors that are imagined as 'the elite' should act collectively to defend and pursue their collective interests. Narrowing the definition of 'the elite' tightens the definition of populist discourse. If one accepts this stricter conception of populism, then some discourses which have been classified as populist should be reclassified. By returning to Laclau for these criteria, this article reasserts an earlier conception of 'the elite' in populism consistent with contemporary ideational definitions, rather than inventing a new one. 
Tightening the conception of populism reveals another discourse, christened here 'elitist plebeianism', which bears remarkable similarities to populism but also pertinent differences from it. Elitist plebeians also construct 'the people'. However, they do not bifurcate society between 'the people' and 'the elite'; they trifurcate society, and imbue two groups that it constructs with power. They imbue one with a minority share of power and characterise it as an enemy of the people. They imbue the other, 'the elite', with a plurality of power, and characterise it as a friend and advocate of the people. Therefore, elitist plebeians too create an antagonism along a 'down/up axis' of power. ${ }^{9}$ However, while populists vilify the elite, elitist plebeians heroise 'the elite' and vilify a powerful middle stratum.

While populism and elitist plebeianism bear remarkable similarities, they are also bear dissimilarities, and these differences are discerning. First, populism is anti-elitist, while elitist plebeianism, as the name suggests, is the converse. ${ }^{10}$ Second, populists advocate overthrowing the enemy of 'the people', while elitist plebeians advocate sanctioning them. Third, while populism creates rhetorical contradictions for its proponents as they win power, elitist plebeianism does not. Fourth, the similar terms and structure of populist and elitist plebeian discourses enable politicians to fluidly move between them. This facilitates the transformation of populist discourse into elitist plebeian ones, and visa versa. Therefore, they are paired concepts; the occurrence of one is connected to the occurrence of the other. To conflate these discourses would be to obscure these subtle but significant conclusions. However, this is precisely what treatments of populism, particularly, 'populism in power', have done to date. This article calls for studies to attend to these differences forthwith. 
This article applies that conceptual apparatus to contemporary Tanzania rhetoric. It takes issue with ascriptions of populism to Magufuli. It argues that between 2015 and 2017, Magufuli and his party appropriated opposition discourses by vilifying the corrupt but rhetorically relocated corruption to the bureaucracy. They portrayed themselves as a virtuous elite that fought corruption on behalf of 'the people'. In other words, they articulated an elitist plebeian message rather than a populist one. While Magufuli did not portray himself as in conflict with 'the elite', many commentators did. Therefore, Magufuli did not express a populist discourse, he was sometimes characterised through the them. The examination of political messages in Tanzania offers a proof of concept. It fastens elitist plebeianism to a real-world case and it illustrates potential of this conceptual apparatus to reinterpret so-called 'populists in power'.

\section{Defining 'the elite' in populism}

Rival approaches to populism define it as a strategy or style, a thin ideology and a discourse. ${ }^{11}$ This article focusses on ideational and discursive approaches of populism. These two approaches disagree on points of ontology and normative orientation. ${ }^{12}$ Nonetheless they agree in numerous respects as recognised by exponents of each. ${ }^{13}$ Each is constituted by sets of ideas or a discourse about how the social world is and ought to be. ${ }^{14}$ At a minimum, they present the social as divided into 'the people' and 'the elite' who are constructed as homogenous and relate as enemies; they claim that it ought to be ruled by 'the people'.

Putting aside disagreements between approaches, there is considerable divergence in conceptions of populism within these two approaches. Canovan conceived of populism 
as a political discourse that claimed to represent the interests of 'the people' against their 'enemies'. ${ }^{15}$ Some have suggested that these enemies may take a variety of forms,${ }^{16}$ or even that the invocation of 'the people' alone is sufficient for a 'thin' conception of populist discourse. ${ }^{17}$ This conception grants considerable discretion in the classification of discourses as populist, which has been exercised liberally in subSaharan Africa. For example, Henning Melber, who invokes Canovan, identifies the then long-ruling presidents of Zimbabwe, Namibia and South Africa, Robert Mugabe, Sam Nujoma and Jacob Zuma, respectively, as populists. ${ }^{18}$ However, conventional ideational conceptions stipulate a stricter conception of 'the other' to which 'the people' relate antagonistically. They stipulate that for a discourse to be populist, 'the people' must be pitted against 'the elite'. ${ }^{19}$

However, the identification of populist discourses in practice has been frustrated by the under-specification of what qualifies as the discursive creation of 'the elite'. Indeed, Cas Mudde remarks that 'Although the elite is the anti-thesis of the people, it has received much less theoretical attention in the populism literature'. ${ }^{20}$ The conventional criterion used to define the elite is its power. However, without further elaboration, this criterion is ambiguous. Power takes many forms, and it is not specified how much a group must have or how the actors within that group must relate to one another to constitute an elite. The lax definition of 'the elite' has become a conceptual back door for the classification of discourses as populist, especially in Africa. For example, Danielle Resnick, ${ }^{21}$ Giovanni Carbone ${ }^{\mathrm{i}}$ and Benjamin Moffitt have all claimed that Yoweri Museveni of Uganda employs an anti-elite, populist discourse. ${ }^{22}$ However,

\footnotetext{
${ }^{\text {i }}$ Giovanni Carbone explicitly holds back from defining Museveni as a fully-fledged populist.
} 
Richard Volkes and Sam Wilkins argue that Museveni presents himself as supremely powerful, even 'monarchical', and he does so with cause; he has ruled Uganda continuously since 1986. ${ }^{23}$ Therefore, paradoxically, Museveni both imbues himself with unrivalled power, and vilifies the powerful. Similarly, Ian Khama has been identified as a populist with an anti-elite discourse, even though he was the son of Botswana's first president and led a party which had ruled for 42 years continuously upon his nomination. ${ }^{24}$ Likewise, several identify Zuma's discourse as populist not only when he was running for the leadership of the African National Congress (ANC), opposed by the incumbent, ${ }^{25}$ but years after he had become its leader. ${ }^{26}$ In sum, politicians and discourses have been identified as populist in part because so little is stipulated about what constitutes 'the elite'. Populism has even been redefined based on the features of this expanding population of cases. ${ }^{27}$ These centrifugal pressures on the boundaries of the concept stretch its coherence thin.

This article advances tighter criteria that a discourse must meet to qualify as populist. Specifically, it advances a stricter definition of how a social category must be constructed for it to be recognised as 'the elite'. This does not concern the veracity of the discourse, but the characteristics with which the social group is discursively imbued. Therefore, this discussion makes only fleeting reference to the literature on the study of elites and power. Instead, it returns to Laclau. This article derives three criteria that a discourse must meet in its construction of 'the elite' to qualify as populist.

The first criterion concerns the distribution of power that populist discourses construct. Laclau stipulates that populist discourses involve the "construction of the "people" and "power" as antagonistic poles. ${ }^{28}$ Therefore, they necessarily imbue 'the elite' with 
more power than 'the people'. Laclau also stipulates that populist discourses 'divide, in this way, the social into two camps: power and the underdog' ${ }^{29}$ This bifurcation of society entails that 'the elite' and 'the people' possess all power between them.

Therefore, 'the elite' holds not just a plurality but a majority of power in a society. The definition of power, its commensurability, and its aggregation are all problematic, and merit their own theorisation. Nonetheless, all that matters for the purposes of this article is that power, however the discourse construes it, thus distributes it. Consequently, following Laclau, a discourse which constructed an 'elite' by imbuing this group with status, or wealth, or education, or indeed any other social advantage would not be populist unless it also portrayed them as unrivalled holders of power.

The second criterion conditions the first. It concerns across what domains 'an elite' holds power. Power might be discursively created in many 'fields' that one might care to conceptualise, such as the political, the economic, the intellectual, or the cultural. One might also construe an actor with power in one field, but not another. Therefore, one might imagine a variety of segmented elites located in 'Washington', 'Wall Street', 'Hollywood' and so on. However, populist discourses, conceptualised by Laclau, which 'divide...the social into two camps' leave no room for these pluralist constructions. Instead, they construct simplified world views in which one elite holds a majority of power, when aggregated across all domains in which it is found. Therefore, a discourse which referred to, for example, a cultural elite, would only be populist if it presented this cultural elite as conjoined with or integrated into 'the elite' which held power across fields, although not necessarily a majority in each. 
The third criterion concerns the construction of an elite as a collective actor. If populist discourses, as Laclau puts it, 'divide society into two camps' ${ }^{30}$ then 'the elite' ought to constitute a real social actor. To qualify as populist, a discourse ought to imagine that 'the elite' has collective interests which it acts concert to defend and pursue. Therefore, it must imagine that 'the elite' behaves as a 'ruling class'. ${ }^{31}$

In sum, populist discourses, here defined, portray 'the elite' as a collective actor which holds power across fields and has more of it than the rest of society put together. This conceptualisation follows directly from Laclau's conceptualisation of populist discourse. However, they are also applicable to, and derivable from, ideational approaches to populism which are non-Laclaudian, notably those of Mudde, Hawkins and Kaltwasser, among others. These approaches stipulate that populism develops a 'world view' that sees politics as a 'struggle between...the common people and an evil, conspiring elite'. ${ }^{32}$ They also stipulate that populisms conceive of 'the people' and 'the elite' as 'homogenous' and are committed to 'antipluralist' ideas about what society is and ought to be. ${ }^{33}$ The aforementioned three criteria have been designed for consistency with these ideational approaches, and to keep faith with their apparent conception of 'the elite' in populism. They also closely mirror Schedler's conception of anti-politicalestablishment parties. They are reflected in imaginations of 'the elite' ascribed to populisms in the literature as the 'power-holders', 'the establishment' and ' $l a$ oligarquía'. Therefore, far from advocating a radical departure in conceptualisations of populism, this article proposes a conception of 'the elite' which restores its scholarly meanings common to both discursive and ideational approaches. 


\section{Elitist plebeianism}

This strict definition of populism makes it possible to distinguish another type of discourse referred to here as elitist plebeianism. This discourse is closely related to populism. However, the stricter definition of the elite advanced above throws their differences into relief. An elitist plebeian discourse interpellates social actors as 'the people' through logics of equivalence. It generates an antagonism between 'the people' and to another group which frustrates its demands. This antagonism is arrayed along, to borrow a term from Benjamin de Cleen, a 'vertical axis' of power. ${ }^{34}$ In these respects, elitist plebeian and populist discourse are alike. However, in elitist plebeian discourses, two groups are constructed above the people. One is presented as a middle stratum and imbued with a minority of power. Another is presented as 'the elite' and imbued with a plurality of power. In elitist plebeian constructions of the social, the middle stratum relates to 'the people' antagonistically. By contrast, 'the elite' relates to the people harmoniously. It may not be of 'the people', but it serves as it's advocate against a middle stratum. In other words, society is divided into at least three groups between 'the people', a middle stratum and 'the elite'. The middle stratum is vilified, while 'the elite' is heroised. The middle possesses enough power to predate on 'the people' but may not possess enough power to actively resist 'the elite'. Some conceptions of populist discourses specify that the populist leader is constructed as a distinct third actor ${ }^{35}$ or a signifier of 'the people'. ${ }^{36}$ However, elitist plebeian discourses imbue the virtuous elite with a plurality of power, while populist discourses do not thus imbue populist leaders.

Recognising a discourse which trifurcates involves a partial break with Laclau and Mouffe. They stipulate that antagonisms do not 'admit tertium quid', the existence of 
third element. ${ }^{37}$ For them, an antagonism is generated through the expression of 'fighting demands'. An identity 'bloc' is formed by rendering actors' demands equivalent. This is only possible through reference to the shared 'other' against which demands are made. This creates a social frontier. The identity bounded by this internal frontier is taken as the social totality; 'the people' is conceived of as 'the mass'. ${ }^{38}$ Therefore, as Nadia Urbinati puts it, populist discourses represent a part of society as its whole, or pars pro toto. ${ }^{39}$ This representative claim makes these antagonisms innately radical. If 'the people' are truly the whole, 'the elite' are external to society and ought to be overthrown. Therefore, they conclude, antagonisms innately divide society into two camps.

However, Laclau and Mouffe also hold open the possibility that these antagonisms play out incompletely. Therefore, they do not bifurcate society, nor necessitate the claim that 'the mass' represents its whole. They suggest this several times in their early work. ${ }^{40}$ In his later work, Laclau describes hypothetical chains of equivalence which do not always reach the edges of 'the social'. ${ }^{41}$ Discourses generated from such partial logics would not bifurcate the social and so would not foreclose the possibilities of third or further identities. Nor would the antagonisms take on the totalising and revolutionary representative claims by which the part claims to be the whole, consistent with 'a lessening of the charge of negativity attaching to the antagonisms' which Laclau and Mouffe describe ${ }^{42}$ Elitist plebeianism belong to this middle realm of discourses.

Elitist plebeians do not contend that 'the people' are or ought to be the whole, but that they are the lowest of three enduring strata. The antagonism between 'the people' and the middle which gives each their identity involves sanctioning or subduing, but not 
overthrowing, the middle. This sanction is to be served by 'the elite' on behalf of 'the people'. This conception of 'the people' closely resembles 'the underdog', 'common people', and 'subaltern', which scholars postulate that populists construct. ${ }^{43}$ 'Elitist plebeianism', derived from the Latin plebes, seems a fitting term for such a type of discourse which draws out how it differs from populism.

Laclau identifies in passing 'the populism of the dominant classes ${ }^{44}$ Separately, he describes depoliticising discourses whereby demands are met and antagonistic identities dissembled, which one-nation conservatism exemplifies. ${ }^{45}$ In some respects, elitist plebeianism is similar to both of these discourses. Nonetheless, it is distinct from each. Laclau stipulates that populisms of the dominant classes seek to develop but contain the 'revolutionary potential of popular interpellation', ${ }^{46}$ a contradiction between their discourse and objectives with which they struggle to cope. Therefore, while dominant classes employ populist discourses, they are ill-adapted to serve their hegemonic purposes, because their natural conclusion is revolutionary. However, as elitist plebeian discourses do not claim that 'the common people' is or ought to be the whole, elitist plebeian discourses do not necessarily contain this contradiction. In fact, as they are not wedded to social transformation, they are potentially compatible with principles of natural aristocracy and class harmony found in conservative thought. ${ }^{47}$ Unlike depoliticising one-nation discourses, elitist plebeianism constructs antagonisms between 'the common people' and the middle, and advocate that 'the elite' subdue the latter on the former's behalf.

Elitist plebeian discourses also lend themselves to certain strains of socialist thought. Laclau and Mouffe advocate that socialists develop radical populist discourses. ${ }^{48}$ 
However, a variety of Marxist-Leninist movements in power portrayed themselves as 'vanguard' elites. ${ }^{49}$ As Laclau and Mouffe remark, the Leninist tradition 'postulates a clear separation within the masses between the leading sectors and those which are led. ${ }^{50}$ A Marxist-Leninist discourse would employ the language of class, exploitation, and relations of production. However, a discourse that rendered 'working class' and 'the people', 'vanguard' and 'elite' and other pairs of terms partially or wholly equivalent would be elitist plebeian too. Like populisms, Marxist-Leninist discourses forecast the socialist transformation of society, by which the 'the people' or 'the working class' become the whole in a classless society. However, vanguardism casts that moment into the distant future, creating the space for the vanguard elite to act on behalf of the people against a middle stratum in the interim. Thereby, elitist plebeian discourses can nest within discourses with long-term transformative agendas.

These theoretical moves serve clarificatory purposes. They illuminate and attend to sites of theoretical ambiguity which have led to mis-identification and concept-stretching. However, the difference between elitist plebeianism and populism is also consequential. Each serves types of political projects better than others. A natural normative conclusion of a populist argument is that an establishment should be dethroned. A natural conclusion of an elitist plebeian argument is that the excesses of some middle stratum should be quelled. Therefore, populist discourses face tensions between holding power and confronting it, but elitist plebeian discourses do not. By virtue of these rhetorical structures, populist discourses lend themselves to radical political projects which involve casting out an elite, or the performance thereof. By contrast, elitist plebeian discourses lend themselves to the projects of established orders seeking to curtail the privileges and powers of assertive strata in the middle, or the performance 
thereof. Similarly, they lend themselves to projects of authoritarians seeking to oppress civil society.

While elitist plebeian and populist discourses are distinct concepts, they also form a pair. Populist and elitist plebeian discourses have similar terms, repertoires and discursive structures. These similarities enable politicians to smoothly switch between one discourse and the other. Populists that are elected to public office are likely to jettison their populism in favour of elitist plebeianism which resolve the contradictions between their positions of power and their vilification of the powerful. Therefore, an elitist plebeian discourse provides a ready-made script for a so-called 'populist in power'. Similarly, politicians in power may appropriate populist messages incubated in opposition by developing equivalent elitist plebeian ones. This convertibility goes both ways. Elitist plebeians may adopt populist discourses once they lose power, and opposition politicians may appropriate ruling parties' elitist plebeian messages by rendering them populist. Therefore, while each discourse may be articulated independent of the other, the expression of one is likely to be connected to the prior expression of the other.

As elitist plebeianism constructs a benevolent elite which holds power, it is does not lend itself to expression by politicians in opposition. In most societies, out of office entails out of power. However, it does not in all societies. Nor are discourses faithful to reality. An elitist plebeian message could be articulated which imagines an elite with power beyond and above government. Aristocratic conservative parties have expressed such optimas discourses. Robert Gasgoyne-Cecil (Lord Salisbury) may have spoken in such terms when he led the opposition from the House of Lords and vilified 'that 
secular representation of the Inquisition, the modern inspector' ${ }^{51}$ Parties representing business could conceivably portray themselves as patricians that wield power even in opposition. Military institutions adopt elitist plebeian discourses when they present themselves as hitherto dormant praetorian protectors of 'the people' that intervene in civilian politicians to discipline wayward politicians. While not beyond the state, they are beyond government. The rhetoric of Egypt's armed forces during the 2013 coup is a good example. Constitutional monarchies have also portrayed themselves as similar 'sleeping guardians' of 'the people'. The Thai monarchy's conduct during the 2014 coup and 2019 election is a case in point.

This article applies these concepts to interpret CCM rhetoric in Tanzania during Magufuli's first two years in office. Analysing discourse presents particular methodological challenges, in particular interpreting meaning, situating meaning, distilling coherence and determining how exhaustively to gather sources. ${ }^{52}$ The author faced the additional challenge that he is not fluent in Swahili. To address these challenges, he studied a wide range of sources. He collected the transcripts of and video footage of numerous political speeches. He examined political rhetoric and performance reported through third parties, particularly the press, which he collected in a personal archive of over 1,900 articles. He examined third-party commentaries on Tanzanian politics. He examined a grey literature of party manifestoes, party documents, and government reports. To ensure that he did not misinterpret what politicians said and did not overlook sources that would alter his analysis, he interviewed Tanzanian political commentators, and conferred informally with many more. These peers offered insights and interpretation which have influenced this article. They are recognised in the acknowledgements. 


\section{'Leader of the downtrodden'}

Magufuli, a career CCM politician, was nominated as his party's presidential candidate in August 2015 as President Jakaya Kikwete finished his second term. During those two terms, CCM became increasingly associated with grand corruption. CCM had been accused of corruption recurrently since the reintroduction of multiparty democracy in 1992. ${ }^{53}$ Partly because of a persistently 'unlevel playing field', ${ }^{54}$ CCM's image had endured. ${ }^{55}$ However, between 2004 and 2015, an opposition party Chadema ${ }^{\text {ii }}$ founded branches nation-wide. ${ }^{56}$ Using this apparatus, and its rallies,${ }^{57}$ it successfully characterised the apex of CCM as an establishment ridden with corruption. It portrayed the hardship of Tanzanians as the consequence of that corruption. This imaginary was reified by a succession of grand corruption scandals which emerged during Kikwete's presidencies, ${ }^{58}$ which publicly-aired CCM factional conflicts only reinforced. ${ }^{59}$

Magufuli appropriated this opposition discourse by declaring a 'war' on corruption. ${ }^{60}$ On his first day in office, he paid an impromptu visit to the Ministry of Finance, found that officials were away from their desks, and chastised their superiors on camera. Days later, he visited Muhimbili Hospital, found equipment missing, and suspended its Board of Directors. He presented his actions as the disruption of the status quo. His chief secretary explained that 'The president is trying to send a message... It's not business as usual' 61

\footnotetext{
ii Chama cha Demokrasia na Maendeleo or 'The Party of Democracy and Development'.
} 
Magufuli and his party sought out corruption not only in the state but among big business, the very sort of actors with whom the opposition alleged CCM colluded. Julius Nyerere, the first President of Tanzania, had articulated an African socialist programme. This programme took ending exploitation and stemming emergent capitalism as its explicit objectives. ${ }^{62}$ Magufuli and CCM borrowed from Nyerere's discourse but shore it of its socialism. For example, they used terms from the socialist period $^{63}$ such as 'unyonyaji' ${ }^{64}$ or 'exploitation'. However, they tended to describe instances of exploitation without reference to the ownership of capital or the mode of production. Instead, they denounced illicit activities which involved abuses of power. As Magufuli dismissed civil servants for falsifying their qualifications, he said 'They are thieves like any other thieves'. ${ }^{65}$ In this respect, their elitist plebeianism was postsocialist, rather than socialist. ${ }^{66}$

For example, in the agricultural sector, the government repossessed 'those holding large areas and farms without developing them'. ${ }^{67}$ The implication was that assets had been acquired under false pretences and mis-used. Regarding the industrial sector, Magufuli complained of investors that 'we hand them our factories and then only end up doing nothing about developing them. ${ }^{98}$ Magufuli not only portrayed big business as disingenuous, but corrupt. In the mining sector, Magufuli intervened in the forcible removal of small-scale miners from land which was licensed to others. He alleged that large-scale mining companies had acquired permissions for the land illicitly by bribing officials. ${ }^{69}$ Bribery is primarily an instrument of the rich. Magufuli remarked that 'the 
rich people have many ways to do/use corruption. ${ }^{\text {iii }}{ }^{70}$ In sum, Magufuli and CCM vilified illicit business, rather than capitalist accumulation, though as Nyamsenda points out, he vacillated in preference for foreign and domestic capitalists. ${ }^{71}$

Magufuli often portrayed the common people as the victims of the corruption described above. For example, government officials were characterised as predatory. He chastised government officials that had forcibly moved street traders. ${ }^{72}$ He remarked of corruption that 'those involved [in corruption] are not the ordinary mwananchi', or citizens. ${ }^{73}$ Similarly, the illicit mining licensing described above was framed to generate antagonisms between people and corrupt business. Magufuli argued that 'We can't dislodge 5,000 small-scale miners for the sake of just one investor. ${ }^{, 74}$ Likewise, he instructed officials to 'confiscate all undeveloped farms and allocate them to wananchi who will develop them'. ${ }^{75}$ Magufuli used the term wananchi, or 'citizens', in conjunction with a succession of terms to signify 'the common people'. He described how 'the government... disturb the poor, while letting the rich go free' ${ }^{\text {iv }}{ }^{76} \mathrm{He}$ stated that 'I know that many live low lives'. ${ }^{77}$ He declared himself 'kiongozi wa wanyonge', or 'leader of the downtrodden. ${ }^{78}$ Regarding taxation, he said 'We should not let the small people struggling to suffer under the weight of nuisance council taxes yet the big

iii Original text: 'Matajiri wana mbinu nyingi za kuchezea rushwa.' I owe thanks to Aikande Kwayu for correcting me on the best way to translate this.

iv Original text: 'Serikali... inawaacha matajiri inawasumbua masikini'. I owe thanks to Aikande Kwayu for correcting me on the best way to translate this.

v Original text: 'Najua Tanzania watu wengi wanaishi maisha ya chini'. 
boys were evading to pay tax. ${ }^{79}$ In these instances, lowness and size served as metaphors for powerlessness.

In sum, Magufuli and his party expressed a discourse which bore many of the hallmarks of populism. Nonetheless, this article contends that Magufuli's message was not populist by the criteria developed above.

\section{The CCM leadership versus the bureaucrats}

While Magufuli stressed the evils of corrupt, he did not construct the perpetrators of corruption as an elite. Days after his nomination as CCM's presidential candidate, he declared 'I don't like lazy public officials; if God makes me your next president I will effectively deal with lazy officials' ${ }^{80}$ Weeks later, he declared that 'this country has enough money but is being embezzled by corrupt officials' ${ }^{81}$ Bureaucrats, rather than 'the establishment' became the source of corruption as he portrayed it. In effect, Magufuli and his party relocated corruption from the zenith of the party to the bureaucracy. There is both reason and precedent to single out the bureaucracy for political action. Like in many post-colonial states, bureaucrats enjoyed extensive power in Tanzania in the colonial period, and in the one-party period that followed. Issa Shivji singles out the bureaucratic bourgeoisie as the dominant class in post-colonial Tanzania. ${ }^{82}$

Magufuli characterised bureaucrats as 'powerful people' with enough power to predate upon normal people. ${ }^{83}$ However, he imbued them discursively with much less power 
than himself and the CCM leadership. This is evident not only in his words but his actions. By dismissing 10,000 government employees, he construed the agents of corruption as thousands of petty bureaucrats. ${ }^{84}$ Similarly, video footage captured Magufuli's visit to the Ministry of Finance. It showed him startling staff and then haranguing their managers. As one newspaper reported, his visit sent:

'staff into panic mode, with some scampering for cover as others simply froze in their track. His unexpected presence overwhelmed scores of employees and the few he beckoned over could be seen trembling. ${ }^{95}$

Panicking, hiding, freezing and trembling are all acts of the frightened, rather than the powerful. Equally, Magufuli's dramatic, on-the-spot firings were displays of his executive authority, and officials' subservience to him. ${ }^{86}$ His performances emphasised his power, rather than theirs. Equally, Magufuli and his party did not suggest that the bureaucracy acted in concert to resist his reforms. The war on corruption which they discussed was drawn-out because the corrupt are multitudinous and covert, not because they were organised or fighting back. In the absence of such suggestions, the picture which he created was one of widespread but uncoordinated malfeasance.

This is not to say that Magufuli never located corruption in CCM's leadership. He fired ministers for alleged inaction on corruption. However, on these occasions, he portrayed supposed wrong-doers as errant individuals, rather than members of an establishment. On one occasion, he described politicians that were holding up the appointment of a drugs commissioner-general as 'bad apples' ${ }^{87}$ His decision to underplay, rather than overplay the power and privilege of such individuals is illustrative. These presented rhetorical opportunities to construct a picture of corruption and the zenith of the party which Magufuli deigned not to take. 
Similarly, Magufuli and his party rarely suggested that business organised to resist him or had the power to do so. Instead, he suggested that illicit businesses were forever struggling to evade the authorities. During the sugar shortage, Magufuli suggested that stocks of sugar were 'hidden'. He warned traders that 'they are only playing with their own survival. ${ }^{98}$ The frequent repossessions of land, reclamation of factories and standoffs with foreign companies all served to emphasise the president and the party's power at the expense of those of business.

Magufuli presented his presidency as a rupture with the status quo. However, he characterised it as an order with beneficiaries but without architects or defenders. $\mathrm{He}$ attributed the emergence of this order to errors of judgement by past leaders. He said that during the 1990s, 'we privatised even strategic industries like the railways corporation. It's like we decided to leave each and everything to investors, which was wrong. ${ }^{89}$ Therefore, while he portrayed himself as a 'new broom', he did not portray this break in populist terms.

Magufuli's cabinet and the party leadership have followed his lead and theatrically joined Magufuli's struggle against corruption. For example, the Minister of Home Affairs, Kangi Lugola, sent the Prisons Commissioner out of a meeting for arriving one minute late. ${ }^{90}$ He dissolved three government bodies for gross ineptitude. ${ }^{91}$ His emphasis on officials' punctuality and impropriety was consistent with Magufuli's emphasis on their moral shortcomings. His maverick, strict style mirrored Magufuli's own, and cast him as the disciplinarian that would reign-in miscreant bureaucrats. Another minister declared that 'I am aware that these malpractices are going on in the 
port of Dar es Salaam. The days of such workers... are numbered. ${ }^{92}$ A permanent secretary told bureaucrats that the government would 'take stern measures against any worker going against the law. ${ }^{93}$ In a similar vein, maverick Dar es Salaam Regional Commissioner Paul Makonda waged war on the drugs trade which singled out opposition politicians, celebrities, bureaucrats and billionaires. ${ }^{94}$

These politicians have performatively widened the circle of senior leaders that are participants in the fight against corruption. Equally, they have dramatically reinforced the impression that this top rung of politicians goes unchallenged. Much of CCM's paternal elitism remained implicit. However, CCM expressed the role it imagines for itself. CCM's Secretary-General, Bashiru Ally, gave ideational coherence to CCM's performances. He declared that CCM 'arrests exploiters, thieves, those misappropriating public funds, and teaches them a lesson. ${ }^{95}$ Another CCM grandee, Salim Salim, remarked that ' $\mathrm{CCM}$ will carry on with the responsibility of fighting for the rights of the downtrodden. ${ }^{96}$ Magufuli said that ' $\mathrm{CCM}$ members are moving forward to bring a new Tanzanian which fights for the downtrodden'. vi 97 Equally, CCM expresses its virtues. Prime Minister Kassim Majaliwa said Tanzania’s leaders should be, and were 'ethical, patriotic and pioneers of unity. ${ }^{\text {vii }} 98$ Former president Kikwete said that 'CCM has courageous, versatile and creative leaders'. ${ }^{99}$ Equally, its repeatedly boasted of its power and permanence. Kikwete said 'CCM is a strong party and will remain that way

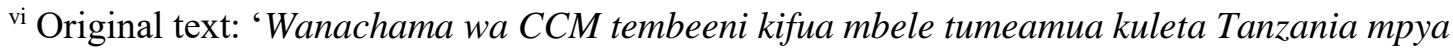
inayowapigania wananchi hasa wanyonge'.

vii Original text: 'viongozi waadilifu, wazalendo na wenye kulinda amani na kudumisha umoja katika jamii.'
} 
forever.' ${ }^{100}$ Similarly, Magufuli said that ' $\mathrm{CCM}$ is a ruling party and will continue to rule forever'. viii ${ }^{101}$ While Magufuli often claimed to be pursuing the people's interests, he rarely claimed to represent an embodiment of express will of 'the people'.

Pedersen and Jacob classify Magufuli as populist because of his 'performative political acts. ${ }^{102}$ In doing so, they invoke Moffit and Simony Tormey, who conceive of a 'populist style'. ${ }^{103}$ The examples above show that while Magufuli and his party behaved dramatically, his performances did not enact a populist discourse, but an elitist plebeian one. They construct society in trichotomous, rather than dichotomous, terms. In effect Magufuli appropriated the opposition critiques levelled against his party but stripped them of their anti-establishment character. This discursive transition was eased by the rhetorical similarity between populist and elitist plebeian discourse. The message that he espoused made it straightforward to oppose the enemies of 'the downtrodden' while portraying himself and his party as an elite.

From March 2017, and onwards, Magufuli increasingly elevated a nationalist dimension in his discourse. ${ }^{104}$ He used the alleged discovery of mineral exports by Acacia Mining to construct an 'economic war' between Tanzania and foreign actors. Unlike his previous elitist plebeianism, this discourse arrayed a second conflict across international boundaries in which the nation's opponents were sometimes portrayed as more powerful than Tanzania. For example, he declared that 'there is no country being robbed of its mineral wealth like Tanzania'. ${ }^{105}$ This new front in Tanzania's struggle overlaid nationalism and populism, in the way conceptualised by de Cleen. ${ }^{106}$ Therefore,

\footnotetext{
viii Original text: 'CCM ni chama tawala na kitaendelea kutawala milele'.
} 
Magufuli expressed an elitist plebeian discourse most singularly from his nomination in July 2015 until March 2017.

\section{Ambiguity and populist interpretations of Magufuli}

While Magufuli and his party leadership did not present themselves in populist terms, many others did. The source of this divergence in interpretations arose from the circumstances of his nomination as CCM's presidential candidate. The most prominent contestants in the nomination race were Bernard Membe and Edward Lowassa. Both were widely perceived to be at the heart of CCM elite politics, to be wealthy, and supported by powerful factions.

In contrast, Magufuli was portrayed as peripheral to this factionalism. Erick Kabendera wrote of Magufuli that 'the new president has not been nearly as engaged in CCM as his predecessors'. ${ }^{107}$ This underscored his apparent distance from power. In CCM's multistage process, Lowassa was eliminated from the shortlist of candidates, and then Membe was. As Michaela Collord eloquently summarised, 'Two rival factions... knocked each other out of the nomination race. ${ }^{108}$ Consequently, Magufuli's nomination was interpreted as an accident. Elsie Eyakuze called him 'Magufuli the unexpected'. ${ }^{109}$ This is not the only plausible interpretation. Some have speculated that Magufuli's nomination was orchestrated by party grandees, ${ }^{110}$ a possibility that the author of this article is unable to rule out. However, Magufuli benefited from this ambiguity. His apparent happenstance nomination encouraged commentators to interpret his presidency in populist terms. If Magufuli was nominated by chance, then he was free of the CCM system. 
The opponents in the war on corruption were constructed as an elite. Kabendera constructed elite enemies for Magufuli within the party.

'The strategic decision to separate Magufuli from CCM during the 2015 election was a smart campaign move, but... CCM insiders may be regretting it.' ${ }^{111}$

Ali Mufuruki, an enthusiastic advocate of Maugfuli, constructed an elite opposed to his anti-corruption programme both within and beyond the state.

'Criminal networks, racketeers, and private sector beneficiaries of corruption will no doubt work in alliance with their friends in government to ensure that anticorruption institutions do not gain strength.' ${ }^{112}$

In fact, the author of this article has propagated such views. He wrote that 'politicians are trapped in this entrenched system of money politics. But Magufuli has challenged... vested interests in CCM. ${ }^{113}$ Therefore, these parallel interpretations allowed Magufuli to represent different mixtures of change and continuity. Thereby, he reconciled a response to populist critiques with limited upheaval within his own party.

\section{Beyond Tanzania}

This article has advanced a stricter definition of populist discourse by tightening the definition of the elite. The clarity of this stricter definition made it possible to advance a distinct sort of discourse: elitist plebeianism. The distinction between the two is discerning; it illuminates differences in the Tanzanian case. Employing a looser conception of populism would have obscured the differences between CCM discourse and past opposition discourse. Equally, it would have obscured the difference between the discourse articulated by Magufuli and CCM, and the discourses expressed by others 
to interpret them. Tanzania is an exemplar case of elitist plebeianism, but the concept has far-reaching implications. Many discourses which have been classified as populist, especially populism in power, should be re-analysed in light of the categories developed above.

Historically, many socialist one-party states in Africa expressed elitist plebeian discourses. Like Marxist-Leninist regimes, discussed above, most advocated the eventual transformation of society. Many stipulated that this would involve participatory mode of one-party governance which entailed that government was not only of or for but by 'the people'; 'the people' would constitute the party and ruled through it. Some, such as Nyerere, ${ }^{114}$ sometimes claimed that they already did so. Such claims amount to the description of a form of direct rule and do not qualify as elitist plebeian. However, most one-party regimes cast into the future the moment that 'the people' would rule directly. Indeed, many contended that the mass was unready to govern. For this reason, Nyerere, Nkrumah, and others extolled the importance of political education of the masses. ${ }^{115}$ Therefore, they claimed that the party leadership which constituted the vanguard elite - ought to rule on their behalves. Nkrumah asserted that 'the intelligentsia' remained a separate category with the responsibility of forming a 'truly enlightened leadership'. ${ }^{116}$ Even Nyerere often recognised the imperfect integration of TANU and Tanzanians. ${ }^{117}$ Perhaps the most explicit version of this elitism was expressed by Leópold Sédar Senghor, who stated:

\footnotetext{
'But the party must do more: it must guide the masses. The consciousness of the mass, who lack education and culture, still remains confused, lost in the fog of animal needs. [Consciousness] can reach the mass only from the outside, from the intellectuals... In other words, the function of the party is that which Lenin assigned to it'. ${ }^{118}$
} 
Many such one-party regimes also vilified exploitative elements in business and bureaucracy. President Sekou Touré of Guinea described such predation, for example. ${ }^{119}$ In such cases, these regimes expressed elitist plebeian discourses.

In fact, elitism plebeianism is a particularly tempting discourse for contemporary liberation parties in southern African. Their socialist heritages yield potentially contradictory intellectual traditions of vanguard elitism, egalitarianism, and preoccupations with bureaucratic bourgeoisies which are resolved in and lend credence to elitist plebeianism. ${ }^{120}$ These parties' long tenures in power make it advantageous to recurrently rhetorically relocate corruption downwards. However, they have been sometimes mistaken for populists.

In South Africa, for example, Zuma expressed a populist discourse as he ran for the leadership of the ANC. ${ }^{121}$ He portrayed his election as an insurrection by the branches, which constituted a popular movement. ${ }^{122}$ As described above, some argue that he remained a populist after his election as president in 2009. However, during the first years of his presidency, his discourse became elitist plebeian in several respects. He vilified mid-level bureaucrats that predated on 'the people' through corruption. His Vice-President said that corruption was 'far worse than anyone imagines. ${ }^{123} \mathrm{He}$ presented himself and the ANC leadership as a scourge of corruption. He promised that 'It won't be like it was before' ${ }^{124}$ In a manner of which Magufuli is reminiscent, he said that 'If any officials are found guilty, they must be fired on the spot, not just redeployed.' 125 The ANC's secretary-general said that 'Within three months of President Zuma being in office, more heads of department have been investigated and suspended for corruption than in 10 years'. ${ }^{126}$ 
Zuma's vanguard elitism was only partial. He maintained that ultimately 'power lies with the branches'. ${ }^{127}$ Nonetheless, he portrayed the ANC's senior officials as leaders pf society with power. He remarked that:

\footnotetext{
'We are no longer fighting to liberate ourselves... We are now running government. We need a cadre who has that understanding: how to run government and succeed. ${ }^{128}$
}

Concordantly, he said that the ANC should be 'a disciplined force of the left with abeyance towards the poor and the working class and also as a leader of society'. ${ }^{129}$ Therefore, while the ANC was linked to the people through the branches, he constructed it as distinct from them, and as powerful. ${ }^{130}$

Beyond Africa, Carlos de la Torre argues that President Hugo Chávez’s authoritarianism in office arose from the convergence of populism and nationalism in his discourse. ${ }^{131}$ However, as president, Chávez spoke and acted in terms consistent with elitist plebeianism. In 2004, after five years in office, he declared a 'war to kill bureaucratism, corruption and idleness ${ }^{\text {ix }}$ in public administration, a platform strikingly similar to Magufuli’s. ${ }^{132}$ This rhetoric was imitated by his successor, President Nicolás Maduro, who said that 'the greatest enemy, silently, that we have in Venezuela always

${ }^{\text {ix }}$ Author translation. Original text: 'guerra a muerte contra el burocratismo, la corrupción, ya le flojera'. 
is the bureaucratism, the corruption and the indolence of the some civil servants. ${ }^{\mathrm{x}}$ Their party stated that Maduro was 'continuing the moral and ethical refoundation of the country initiated by the Supreme Leader, Hugo Chávez. ${ }^{\text {xi } 133}$ Thereby, their 'crusade' was shared, and they were discursively imbued with legitimate power.

President Rodrigo Duterte's so-called 'penal populism'134 appears to have been elitist plebeian in many respects. His self-declared 'war on drugs' targeted not only 'pushers' and 'users', the subaltern 'others' which make it akin to rightwing extremisms. ${ }^{135}$ Rhetorically, it targeted 'drug cartels', with organisation, resources, arms and power. ${ }^{136}$ He declared 'I will kill all the drug lords'. ${ }^{137}$

Similarly, so-called populist in power President Victor Orbán of Hungary had an elitist plebeian aspect. He vilified and attacked academics, NGOs and the press during his third and fourth terms in office. These actors were characterised as 'Soros' mercenaries' as part of his 'stop Soros' campaign. ${ }^{138}$ Therefore, it seems as though they were treated as the agents of a rich, foreign threat; an elitist plebeian discourse was subsumed in one that was primarily nationalist. ${ }^{139}$

\footnotetext{
${ }^{x}$ Author translation. Original text: 'el más grande enemigo, silencioso, que tenemos en Venezuela todos los días es el burocratismo, la corrupción, la indolencia de algunos funcionarios'.

${ }^{x i}$ Author translation. Original text: 'continuar con la refundación moral y ética de la Patria que impulsó el Comandante Supremo Hugo Chávez.'
} 
The examples which I have sketched above, while speculative, illustrate the potential reach of the categories of discourses developed in this article. In each, the application of the stricter definition of populism and elitist plebeianism throws differences in discourse into relief. The past neglect of these differences is revealing in itself; it pays testament to the subtlety of the differences between these discourses, and the smoothness with which politicians have switched between them. It illustrates the revisionist potential of these concepts and raises the intriguing possibility that other elitist plebeianisms have been mistaken for populism. 


\section{Endnotes}

${ }^{1}$ A. Fraser, 'Post-Populism in Zambia: Michael Sata's Rise, Demise and Legacy', International Political Science Review, 38(4) (2017), pp. 456-72; D. Paget, 'Election Campaigns and Political Mobilization in Africa', in Nic Cheeseman (Ed.) Oxford Encylopedia of African Politics (Oxford: Oxford University Press, in press), pp. 10-12; N. Cheeseman and M. Larmer, 'Ethnopopulism in Africa: Opposition Mobilization in Diverse and Unequal Societies', Democratization, 22(1) (2015), pp. 22-50; N. Cheeseman. 'Populism in Africa and the potential for ethnically-blind politics', in Carlos de la Torre (Ed.) Routledge Handbook of Global Populism (London: Routledge, 2018), pp. 357-369.

2 S. Nyamsenda, 'Bulldozing like a Fascist? Authoritarian Populism and Rural Activism in Tanzania', Emancipatory Rural Politics Initiative International Conference: Authoritarian Populism and the Rural World, 2018, available at https://www.tni.org/files/articledownloads/erpi_cp_78_nyamsenda.pdf.

${ }^{3}$ T. Jacob and R. Pedersen, 'New Resource Nationalism? Continuity and Change in Tanzania's Extractive Industries', Extractive Industries and Society, 4(4) (2018), pp. 915-922; J.

Poncian, 'Galvanising political support through resource nationalism: A case of Tanzania's 2017 extractive sector reforms', Political Geography, 69 (2019), pp. 77-88.

${ }^{4}$ The Economist, 'Tanzania's Firebrand Leader Takes on Its Largest Gold Miner', 15 June 2017, available at https://www.economist.com/business/2017/06/15/tanzanias-firebrandleader-takes-on-its-largest-gold-miner.

${ }^{5}$ D. Paget, 'Tanzania: Shrinking Space and Opposition Protest', Journal of Democracy, 28(3) (2017), pp. 153-167.

${ }^{6} B B C$, 'Rais Magufuli asema chama tawala cha CCM 'kitaongoza milele Tanzania', 17 July 2018, available at https://www.bbc.com/swahili/habari-44861468.

${ }^{7}$ M. Canovan, 'Two Strategies for the Study of Populism', Political Studies, 30(4) (1982), pp. 544-552.

${ }^{8}$ E. Laclau, 'Populism: What's in a Name?', in Francisco Panizza (Ed.) Populism and the Mirror of Democracy (London: Verso, 2005), pp. 32-49.

${ }^{9}$ B. de Cleen, 'Populism and Nationalism', in Cristóbal Kaltwasser, Paul Taggart, Paulina Espejo and Pierre Ostiguy (Eds) The Oxford Handbook of Populism (Oxford: Oxford University Press, 2017), pp. 343-362. 
${ }^{10}$ Cas Mudde, 'Populism: An Ideational Approach', in Cristóbal Kaltwasser, Paul Taggart, Paulina Espejo and Pierre Ostiguy (Eds) The Oxford Handbook of Populism (Oxford: Oxford University Press, 2017), pp. 27-47.

${ }^{11}$ N. Gidron and B. Bonikowski, 'Varieties of Populism: Literature Review and Research Agenda', Weatherhead Centre for International Affairs, 2013, available at https://papers.ssrn.com/sol3/papers.cfm?abstract_id=2459387.

${ }^{12}$ Gidron and Bonikowski, ibid.; K. Hawkins and C. Kaltwasser, 'The Ideational Approach to Populism', Latin American Research Review, 52(4) (2017), p. 516.

${ }^{13}$ Mudde, 'Populism', op. cit., Ref. 10; de Cleen, 'Populism and nationalism', op. cit., Ref. 9; K. Hawkins, 'The ideational approach', in Carlos de la Torre (Ed.) Routledge Handbook of Global Populism (London: Routledge, 2018), pp. 65-6.

${ }^{14}$ B. Stanley, 'The Thin Ideology of Populism', Journal of Political Ideologies, 13(1) (2008): pp. 95-110; Mudde, 'Populism', op. cit., Ref. 10; Hawkins, 'The ideational approach', op. cit., Ref. 13; Hawkins and Kaltwasser, 'The Ideational Approach to Populism', op. cit., Ref. 12.

${ }^{15}$ Canovan, 'Two Strategies', op. cit., Ref. 7.

${ }^{16}$ B. Moffit and S. Tormey, 'Rethinking populism: Politics, mediatisation and political style', Political Studies, 62(2) (2014), pp. 381-397; M. Edelman, S. Borras, R. Hall, W. Wolford, and B. White, 'Emancipatory Rural Politics: Confronting Authoritarian Populism', The Journal of Peasant Studies, 45(1) (2018), pp. 1-20.

${ }^{17}$ J. Jagers and S. Walgrave, 'Populism as Political Communication Style: An Empirical Study of Political Parties' Discourse in Belgium', European Journal of Political Research, 46(3) (2007), pp. 319-345.

${ }^{18}$ H. Melber, 'Populism in Southern Africa under Liberation Movements as Governments', Review of African Political Economy, 45(158) (2018), pp. 678-686.

${ }^{19}$ Mudde, 'Populism', op. cit., Ref. 10.

${ }^{20}$ Mudde, ibid., p. 33.

${ }^{21}$ Resnick qualifies this classification in D. Resnick, 'The influence of populist leaders on African democracy', in Carlos de la Torre (Ed.) Routledge Handbook of Global Populism (London, Routledge, 2018), p. 267.

${ }^{22}$ D. Resnick, Urban Poverty and Party Populism in African Democracies (Cambridge: Cambridge University Press, 2013); B. Moffitt, The Global Rise of Populism: Performance, Political Style, and Representation (Stanford: Stanford University Press, 2016); G. Carbone, “"Populism” Visits Africa: The Case of Yoweri Museveni and No- 
Party Democracy in Uganda', Crisis States Programme, 2005, available at http://eprints.lse.ac.uk/28171/1/wp73.pdf.

${ }^{23}$ R. Vokes and S. Wilkins, 'Party, Patronage and Coercion in the NRM's 2016 Re-Election in Uganda: Imposed or Embedded?', Journal of Eastern African Studies, 10(4) (2016), pp. 581-600.

${ }^{24}$ Resnick, Urban Poverty, op. cit., Ref. 22.

${ }^{25}$ A. Sitas, 'The Road to Polokwane? Politics and Populism in KwaZulu-Natal', Transformation, 68 (2008), pp. 87-98.

${ }^{26}$ Resnick, 'The influence of populist leaders', op. cit., Ref. 21; Resnick, Urban Poverty, op. cit., Ref. 22; Moffit, The Global Rise, op. cit., Ref. 22.

${ }^{27}$ Moffit, ibid.

${ }^{28}$ Laclau, 'Populism', op. cit., Ref. 8, p. 40.

${ }^{29}$ Laclau, ibid., p. 38.

${ }^{30}$ Laclau, ibid., p. 42.

${ }^{31}$ A. Schedler, 'Anti-Political-Establishment', Party Politics, 2(3) (1996), pp. 291-312.

${ }^{32}$ Hawkins, 'The ideational approach', op. cit., Ref. 13, p. 60.

${ }^{33}$ Mudde, 'Populism', op. cit., Ref. 10, p. 29; Stanley, 'Thin ideology of populism', op. cit., Ref. 14, p. 29; C. de la Torre, 'Global populism: Histories, trajectories, problems, and challenges', Carlos de la Torre (Ed.) Routledge Handbook of Global Populism (London: Routledge, 2018), p. 2.

${ }^{34}$ de Cleen, 'Populism and nationalism', op. cit., Ref. 9.

${ }^{35}$ Schedler, 'Anti-Political-Establishment', op. cit., Ref. 31.

${ }^{36}$ Laclau, 'Populism', op. cit., Ref. 8.

${ }^{37}$ E. Laclau and C. Mouffe, Hegemony and Socialist Strategy: Towards a Radical Democratic Politics (London: Verso, 2001), p. 129.

${ }^{38}$ Laclau and Mouffe, ibid, pp. 125-127; Laclau, 'Populism', op. cit., Ref. 8, pp. 39 and 48.

${ }^{39}$ N. Urbinati, 'Antiestablishment and the Substitution of the Whole with One of Its Parts', in Carlos de la Torre (Ed.) Routledge Handbook of Global Populism (London: Routledge, 2018), pp. 77-97.

${ }^{40}$ Laclau and Mouffe, Hegemony and Socialist Strategy, op. cit., Ref. 37, pp. 129 and 132.

${ }^{41}$ Laclau, 'Populism', op. cit., Ref. 8, pp. 38 and 40.

${ }^{42}$ Laclau and Mouffe, Hegemony and Socialist Strategy, op. cit., Ref. 37, p. 132. 
${ }^{43}$ M. Canovan, “'People”, Politicians and Populism', Government and Opposition, 19(3) (1984), pp. 312-27.

${ }^{44}$ E. Laclau, Politics and Ideology in Marxist Theory: Capitalism, Fascism, Populism (London: New Left Books, 1977), p. 174.

${ }^{45}$ Laclau, 'Populism', op. cit., Ref. 8, p. 42.

${ }^{46}$ Laclau, ibid., p. 174.

${ }^{47}$ A. Aughey, G. Jones, and W.T.M. Riches, The Conservative Political Tradition in Britain and the United States (London: Pinter Publishers, 1992).

${ }^{48}$ Laclau and Mouffe, Hegemony and Socialist Strategy, op. cit., Ref. 37.

${ }^{49}$ V. Lenin and S. Utechin, What is to be done? (Pekin: Foreign Language Press, 1973), p. 99.

${ }^{50}$ Laclau and Mouffe, Hegemony and Socialist Strategy, op. cit., Ref. 37, p. 55, further discussion pp. 54-59.

${ }^{51}$ D. Steele, Lord Salisbury: A Political Biography (London: Routledge, 2002).

${ }^{52}$ P. Gee, An Introduction to Discourse Analysis: Theory and Method (London: Routledge, 2004).

${ }^{53}$ D. Nyaluke and E. Connolly, 'The Role of Political Ideas in Multi-Party Elections in Tanzania: Refuting Essentialist Explanations of African Political Systems', Irish Studies in International Affairs, 24 (2013), pp. 1-17.

${ }^{54}$ A. Makulilo, 'Unleveled Playfield and Democracy in Tanzania', Journal of Politics and Law, 5(2) (2012), pp. 96-106.

${ }^{55}$ E. Babeiya, 'Multiparty Elections and Party Support in Tanzania', Journal of Asian and African Studies, 47(1) (2012), pp. 83-100; A. Kwayu, 'Politics of Image or can we call it the Image Strategy? \#CCM vs \#Opposition', 19 May 2014, available at http://aikandekwayu.com.

${ }^{56}$ D. Paget, 'The authoritarian origins of well-organised opposition parties: The rise of Chadema in Tanzania', African Affairs, in press (2018).

${ }^{57}$ D. Paget, 'The Rally-Intensive Campaign: A Distinct Mode of Electioneering in Sub-Saharan Africa and Beyond', The International Journal of Press/Politics, in press (2019).

${ }^{58}$ H. Gray, 'The Political Economy of Grand Corruption in Tanzania', African Affairs, 114(456) (2015), pp. 382-403. 
${ }^{59}$ M. Collord, 'The Legislature: Institutional Strengthening in Dominant-Party States', in Nic Cheeseman (Ed.) Institutions and Democracy in Africa: How the Rules of the Game Shape Political Developments (Cambridge: Cambridge University Press, 2018).

${ }^{60}$ Daily News, 'Magufuli Moots Graft Courts', 21 November 2015.

${ }^{61}$ F. Ng'wanakilala, 'Tanzania's New President Sacks Hospital Chief after Surprise Inspection', Reuters, 10 November 2015, available at https://www.reuters.com/article/us-tanzaniapolitics/tanzanias-new-president-sacks-hospital-chief-after-surprise-inspectionidUSKCNOSZ17T20151110.

${ }^{62}$ J. Nyerere, 'The Arusha Declaration: A Declaration Outlining Tanzania's Policy on Socialism and Self-Reliance', in Uhuru na ujamaa: Freedom and socialism (Oxford: Oxford University Press, 1974).

${ }^{63}$ J. Brennan, 'Blood Enemies: Exploitation and Urban Citizenship in the Nationalist Political Thought of Tanzania, 1958-75', Journal of African History, 47 (2006), pp. 389-413.

${ }^{64}$ R. Matowo, 'Dk Bashiru Ataja Korosho Akimshukia Tena Membe', Mwananchi, 3 December 2018, available at https://www.mwananchi.co.tz/habari/Kitaifa/Dk-Bashiru-ataja-koroshoakimshukia-tena-Membe/1597296-4878680-13t6yxp/index.html.

${ }^{65}$ J. Nwamkahe, 'President Magufuli Sacks 9,932 Civil Servants at a Go', The Citizen, 29 April 2017, available at https://www.thecitizen.co.tz/News/President-Magufuli-sacks-9-932civil-servants-at-a-go/1840340-3907102-1htv2cz/index.html.

${ }^{66}$ M-A. Fouéré, 'Julius Nyerere, Ujamaa and Political Morality in Contemporary Tanzania', African Studies Review, 17(1) (2014), pp. 1-24.

${ }^{67}$ K. Makoye, 'Tanzania Seizes “idle” Land from Investors to Return to Poor Farmers', Reuters, 16 June 2016, available at https://www.reuters.com/article/us-tanzania-landrightsfarming/tanzania-seizes-idle-land-from-investors-to-return-to-poor-farmersidUSKCNOYN5GW.

${ }^{68}$ J. P. Magufuli, 'Speech officially inaugurating the 11th Parliament of The United Republic of Tanzania (Dodoma)', 20 November 2015, available at http://tz.one.un.org/mediacentre/statements/186-the-speech-by-h-e-john-pombe-joseph-magufuli-officiallyinaugurating-the-11th-parliament-of-the-united-republic-of-tanzania.

${ }^{69}$ The Guardian, 'Magufuli Orders Removal of Top Mining from Gold Field', 7 December 2016, available at https://www.ippmedia.com/en/news/magufuli-orders-removal-topmining-gold-field.

${ }^{70}$ N. Rweyamamu, 'Magufuli: Tanzania’s New Dawn', The Guardian, 12 February 2016, available at https://www.ippmedia.com/en/columnist/magufuli-tanzania\%E2\%80\%99snew-dawn.

${ }^{71}$ Nyamsenda, 'Bulldozing like a fascist', op. cit., Ref. 2. 
${ }^{72}$ F. Kimboy and J. Musa, 'JPM Halts Eviction of Traders, Miners', The Citizen, 7 December 2016, available at https://www.thecitizen.co.tz/News/JPM-halts-eviction-of-traders-miners/1840340-3477756-yet419z/index.html.

${ }^{73}$ The Citizen, 'Magufuli: My Priorities', 15 November 2015, available at https://www.thecitizen.co.tz/News/Magufuli--My-Priorities/1840340-2965662m73ssd/index.html.

${ }^{74}$ Kimboy and Musa, 'JPM', op. cit., Ref. 72.

${ }^{75}$ The East African, 'Magufuli Orders Seizure and Reallocation of Undeveloped Farms', 14 June 2017, available at https://www.theeastafrican.co.ke/news/ea/Magufuli-orders-seizureof-undeveloped-farms/4552908-3969916-u6lfjd/index.html.

${ }^{76}$ G. Kitalima, 'Magufuli Awaonya Wakuu Wa Wilaya Na Mikoa', EATV, 10 July 2017, available at https://www.eatv.tv/news/current-affairs/magufuli-awaonya-wakuu-wawilaya-na-mikoa.

${ }^{77}$ Kitalima, ibid.

${ }^{78}$ R. Mallya, 'JPM akwea Dreamliner na abiria kwenda Mwanza', Habari Leo, 19 August 2018, available at https://www.ippmedia.com/sw/habari/jpm-akwea-dreamliner-na-abiriakwenda-mwanza.

${ }^{79}$ The Citizen, 'Magufuli', op. cit., Ref. 73.

${ }^{80}$ F. Kimboy, 'Magufuli Cautions Lazy Civil Servants', The Citizen, 15 July 2015, available at https://www.thecitizen.co.tz/News/Magufuli-cautions-lazy-civil-servants/18403402789646-mdwd61/index.html.

${ }^{81}$ The Citizen, 'I'll Give You the Change You Crave, Magufuli Woes Crowd', 19 October 2015, available at https://www.thecitizen.co.tz/News/I-ll-give-you-the-change-you-crave-Magufuli-woes-crowd--/1840340-2920582-format-xhtml-ivhkoc/index.html.

${ }^{82}$ I. Shivyi, Class Struggles in Tanzania (London: Heinemann Educational Publishers, 1976).

${ }^{83}$ Daily News, 'Magufuli Moots Graft Courts', op. cit., Ref. 60.

${ }^{84}$ Reuters, ‘Tanzania's Magufuli Sacks Officials Who Failed to Recall Public Works Budget Figures', 7 November 2017, available at https://uk.reuters.com/article/uk-tanzaniapolitics/tanzanias-magufuli-sacks-officials-who-failed-to-recall-public-works-budgetfigures-idUKKBN1D70E9.

${ }^{85}$ The Citizen, 'JPM Storms Finance Ministry', 7 November 2015, available at https://www.thecitizen.co.tz/News/JPM-storms-finance-ministry/1840340-29459727w2192/index.html.

${ }^{86}$ Reuters, 'Tanzania's Magufuli', op. cit., Ref. 84.

${ }^{87}$ A. Mwakyusa, 'JPM intensifies anti-drug crusade', Daily News, 13 February 2017. 
${ }^{88}$ The Citizen, 'PCCB Arrests Trader in Crackdown on Sugar Hoarding', 8 May 2016, available at https://www.thecitizen.co.tz/News/PCCB-arrests-trader-in-crackdown-on-sugarhoarding/1840340-3194888-format-xhtml-axd4b7/index.html.

${ }^{89}$ L. Kolumbia, 'Magufuli: We Erred in 1990s Sell-Offs', The Citizen, 6 July 2017, available at https://www.thecitizen.co.tz/News/Magufuli--We-erred-in-1990s-sell-offs/18403404000720-r4iebd/index.html.

${ }^{90}$ The Citizen, 'Minister Lugola Kicks out Prisons Commissioner for Being One Minute Late to a Meeting', 6 July 2018, available at https://www.thecitizen.co.tz/News/18403404649410-1 mp47qz/index.html.

${ }^{91}$ M. Chawe, 'Minister Lugola Emits Sparks', Daily News, 6 July 2018, available at https://dailynews.co.tz/news/2018-07-065b3f1a85dacb9.aspx.

${ }^{22}$ The Guardian, 'PS Challenges TBS Staff on Integrity, Shun Corruption', 2 September 2018, available at https://www.ippmedia.com/en/business/ps-challenges-tbs-staff-integrity-shuncorruption.

${ }^{93}$ The Guardian, ibid.

${ }^{94}$ The Citizen, 'Uproar over Makonda List', 9 February 2017, available at https://www.thecitizen.co.tz/News/Uproar-over-Makonda-list/1840340-3805794bfrvq3z/index.html.

${ }^{95}$ E. Msuya, 'Dr Bashiru Drums up Support for CCM at Farmers Meeting', The Citizen, 3 October 2018, available at https://www.thecitizen.co.tz/News/Dr-Bashiru-drums-upsupport-for-CCM-at-farmers-meeting/1840340-4790452-85kl5mz/index.html.

${ }^{96}$ E. Edward and A. Zacharia, 'Magufuli elected CCM chairman', The Citizen, 19 December 2017, available at https://www.thecitizen.co.tz/News/Magufuli-elected-CCMchairman/1840340-4234624-3ie7p3/index.html.

${ }^{97} B B C$, 'Rais Magufuli asema', op. cit., Ref. 6.

${ }^{98}$ Habari Mtaa, 'Nimpongeze Rais Magufuli Kwa Kuhakikisha Anairejesha Nchi Kwenye Misingi - Waziri Mkuu', 12 April 2019, available at https://www.habarimtaa.com/2019/04/nimpongeze-rais-magufuli-kwa.html.

${ }^{99}$ Edward and Zacharia, 'Magufuli elected CCM chairman', op. cit., Ref. 96.

${ }^{100}$ H. Mwangonde, 'Kikwete Leads CCM Onslaught on Ex-Premier', The Citizen, 5 August 2015, available at https://www.thecitizen.co.tz/news/Kikwete-leads-CCM-onslaught-onex-premier/1840340-2820334-format-xhtml-lci62z/index.html.

${ }^{101} B B C$, 'Rais Magufuli asema', op. cit., Ref. 6.

102 Jacob and Pedersen, 'New Resource Nationalism?', op. cit., Ref. 3, p. 4.

${ }^{103}$ Moffit and Tormey, 'Rethinking populism', op. cit., Ref. 16. 
${ }^{104}$ Jacob and Pedersen, 'New Resource Nationalism?', op. cit., Ref. 3.

${ }^{105}$ Staff Reporter, 'COPPER CONCENTRATES EXPORT BAN... It's War, Says Magufuli', The Guardian, 2 April 2017, available at https://www.ippmedia.com/en/news/copperconcentrates-export-ban-its-war-says-magufuli.

106 de Cleen, 'Populism and Nationalism', op. cit., Ref. 9.

${ }^{107}$ E. Kabendera, 'Tanzania's President Magufuli: Man of the People, Man of the Party?', African Arguments, 16 August 2016, available at https://africanarguments.org/2016/08/16/tanzanias-president-magufuli-man-of-the-peopleman-of-the-party/.

${ }^{108}$ M. Collord, 'Tanzania - Where President Magufuli's Political and Economic Strategy Meet', Presidential Power, 17 November 2017, available at https://presidentialpower.com/?p=7222.

${ }^{109}$ E. Eyakuze, 'Why Is Tanzania so Quiet?', Al Jazeera, 10 November 2017, available at https://www.aljazeera.com/indepth/opinion/tanzania-quiet-171110101213334.html.

${ }^{110}$ M. Tsubura, “Umoja Ni Ushindi (Unity Is Victory)”: Management of Factionalism in the Presidential Nomination of Tanzania's Dominant Party in 2015', Journal of Eastern African Studies, 12(1) (2018), pp. 63-82.

${ }^{111}$ Kabendera, 'Tanzania's President Magufuli', op. cit., Ref. 107.

${ }^{112}$ A. Mufuruki, 'Magufuli's One Year in Office: Unwavering War against Graft', The Citizen, 6 November 2016.

${ }^{113}$ D. Paget, '2 years on: Tanzania's Magufuli isn't a bulldozer. He's a magician', African Arguments, 6 November 2017, available at https://africanarguments.org/2017/11/06/2years-on-tanzanias-magufuli-isnt-a-bulldozer-hes-a-magician/.

${ }^{114}$ Nyerere, 'The Arusha Declaration', op. cit., Ref. 62.

115 J. Nyerere, The Arusha Declaration Ten Years After (Dar es Salaam: Government Printer, the United Republic of Tanzania, 1977), p. 23; K. Nkrumah, Consciencism (New York: New York University Press, 1970), p. 100.

${ }^{116}$ K. Nkrumah, Towards Colonial Freedom (London: Panaf Books, 1962), p. 38-39.

${ }^{117}$ Nyerere, The Arusha Declaration Ten Years After, op. cit., Ref. 115, pp. 11 and 18.

${ }^{118}$ W. Skurnik, 'Leopold Sengar Senghor and African Socialism', Journal of Modern African Studies, 3(3) (1965), p. 365.

${ }^{119}$ R. W. Johnson, 'Sekou Touré and the Guinean Revolution', African Affairs, 69(277) (1970), pp. $350-365$, p. 355. 
${ }^{120}$ Johnson, ibid.; E. Hunter, 'Revisiting Ujamaa: Political Legitimacy and the Construction of Community in Post-Colonial Tanzania', Journal of Eastern African Studies, 2(3) (2008), pp. $471-485$.

${ }^{121}$ Sitas, 'The Road to Polokwane', op. cit., Ref. 25.

122 J. Zuma, 'Closing Speech at ANC 52nd National Conference (Polokwane)', South African History Online, 20 December 2007, available at https://www.sahistory.org.za/archive/closing-speech-anc-president-jacob-zuma-anc-20december-2007-52nd-national-conference-polokw.

${ }^{123}$ The Economist, 'He Promises a Big Clean-Up', 15 October 2009, available at https://www.economist.com/middle-east-and-africa/2009/10/15/he-promises-a-big-cleanup.

${ }^{124}$ The Economist, ibid.

${ }^{125}$ The Economist, 'Hold Your Nose: The Smell of Corruption', 5 June 2010, available at https://www.economist.com/special-report/2010/06/05/hold-your-nose.

${ }^{126}$ Mail \& Guardian, 'Mantashe Lauds the Zuma Administration', 27 August 2009, available at https://mg.co.za/article/2009-08-27-mantashe-lauds-the-zuma-administration.

127 J. Zuma, 'Opening Speech at ANC 53 $3^{\text {rd }}$ National Conference (Mangaung)', ENCA, 16 December 2012, available at https://www.youtube.com/watch?v=UXX-whLveOk.

${ }^{128}$ Zuma, ibid.

${ }^{129}$ Zuma, ibid.

${ }^{130}$ For a more extensive treatment of elitism in the ANC see K. Johnson, 'Liberal or Liberation Framework: The Contradictions of ANC Rule in South Africa', in Henning Melber (Ed.) Limits to Liberation in Southern Africa: The Unfinished Business of Democratic Consolidation (Cape Town, HSRC Press, 2003).

${ }^{131}$ C. de la Torre, 'Populism and Nationalism in Latin America', Javnost - The Public, 24(4) (2016), pp. 375-390.

${ }^{132}$ La Nacion, 'Chávez Aboga Contra Neoliberalismo, Corrupción y Burocracia', 15 October 2004, available at https://www.nacion.com/economia/chavez-aboga-contraneoliberalismo-corrupcion-y-burocracia/7RL4KV7G3FF4TMOLDEQG5JUD5Y/story/. 
${ }^{133}$ PSUV, 'La Lucha Contra Corrupción Es La Batalla Contra El Capitalismo', 3 August 2013, available at http://www.psuv.org.ve/portada/maduro-lucha-contra-corrupcion-es-batallacontra-capitalismo/\#.XUhe8XvTVPY.

${ }^{134}$ N. Curato, 'Politics of Anxiety, Politics of Hope: Penal Populism and Duterte's Rise to Power', Journal of Current Southeast Asian Affairs, 35(3) (2016), pp. 91-109.

${ }^{135}$ M. Thompson, 'Bloodied Democracy: Duterte and the Death of Liberal Reformism in the Philippines', Journal of Current Southeast Asian Affairs, 35(3) (2016), p. 39-68.

${ }^{136}$ Philippine Daily Inquirer, 'Duterte: Drugs Found at Sea Sign of Colombia Cartel in PH', 27 February 2019, available at https://newsinfo.inquirer.net/1090170/duterte-drugs-found-atsea-sign-of-colombia-cartel-in-ph.

${ }^{137}$ S. Coronel, “'I Will Kill All the Drug Lords”: The Making of Rodrigo Duterte', The Atlantic, September 2016, available at https://www.theatlantic.com/international/archive/2016/09/rodrigo-duterte-philippinesmanila-drugs-davao/500756/.

${ }^{138}$ DW, 'Viktor Orban's Campaign against George Soros "Mercenaries"”, 18 August 2018, available at https://www.dw.com/en/viktor-orbans-campaign-against-george-sorosmercenaries/a-44954661.

${ }^{139}$ de Cleen, 'Populism and nationalism', op. cit., Ref. 9. 